\title{
Burkina Faso Secondary School Pre-Service Teachers Technology Skills
}

\author{
Moussa Moyenga ${ }^{1 *}$, Ertuğrul Usta ${ }^{2}$ \\ 1 Graduate of Educational Sciences School; "Computer Education and Instructional Technology", Necmettin Erbakan \\ University, TURKEY \\ ${ }^{2}$ Head of Computer Education and Instructional Technology (CEIT) Department Necmettin Erbakan University, \\ TURKEY
}

*Corresponding Author: musabote@gmail.com

Citation: Moyenga, M. and Usta, E. (2019). Burkina Faso Secondary School Pre-Service Teachers Technology Skills. Pedagogical Research, 4(1), em0028. https://doi.org/10.29333/pr/5734

Published: March 15, 2019

\begin{abstract}
The purpose of this research was to evaluate the level of Burkina Faso secondary pre-service teachers' technology skills. To reach the aim of the research quantitative research method has been used. Data was collected from 534 pre-service teachers of different departments with 429 male and 105 female from Burkina Faso secondary school teachers education in two institutes, the High Education School of Norbert Zongo University and Institute of Sciences of Ouaga II University on October 2017. Data were transferred to SPSS 22 for statistical descriptives test; t-test and ANOVA tests were applied. According to the results, Burkina Faso secondary pre-service teachers technology skills were so moderate in general and more particularly in basic computer operation (create, save copy and delete files etc...) in use of productivity software (MS Word, Excel, Power Point) and electronic communication (use of e-mail). But their level were low on multimedia (technique of integrating on same medium data of different natures as sound, text video and images...) and electronic references. Comparative analyzes in relation to some variables results indicted a significant difference between the gender; male were competent than female. Meaningful difference has been found between the pre-service teachers' education level. The results showed that pre-service teachers with personal computers were more competent than those without computer. According to the fields of study the result showed significant differences. Technical department pre-service teachers were more competent compare to science, literature and sport department.
\end{abstract}

Keywords: pre-service teachers, technology skills, technology in education

\section{INTRODUCTION}

The rapid development of technology nowadays makes us living in age calling digital age, this age where technology is center of humans' activities has impact on all different sectors of our life. The sector of education didn't stay on the sidelines. Therefore, the integration of technology in education has attracted many researchers around the world in early 1980's. Research demonstrates the importance of technology in education. The integration of technology in education provides opportunities to improve education level and quality (Livingstone, 2010). Information and communication technology (ICT) provides opportunities for educators to use technology in teaching and learning (Usluel et al., 2007; Herzig, 2004). It facilitates the teaching process to teachers as well as the learning process to students. A study conducted by BECTA found that educators and leaners emphasized the positive impact of ICT application on students' access to knowledge (Becta, 2004). 
Many studies have been done to investigate on various topics related to ICT in education. Most of those researches about technology integration in education show that teachers play a crucial role in the integration of technology in education and training processes.

However, lot of researches have shown the positive impact of technology on education by facilitating teaching to teachers. The success of integrating technology in education is base on many factors link to teachers. Many factors can affect the effective use of technology in education. One of the factors is teacher's technology skill towards the use of technology in teaching and learning processes. The importance of technology skills and attitudes has been explained in studies related to the topic (Webb and Cox, 2004; Keengwe and Onchwari, 2008; Hew and Brush, 2007). Technology skill plays an import role. The success of ICT integration in the learning and teaching process mostly depends on the qualifications of teachers (Tezci, 2010). Researchers have suggested that technology skills should be integrated throughout the teacher education curriculum in order to provide pre-service teachers with the skills and experiences needed to apply technology to their specific content areas (Jo et al., 2012)

International organizations such as UNSECO (United Nations Educational Scientific and Cultural Organization) and ISTE (International Society for Technology in Education) have been working to develop tools to measure teachers' technology skill towards the use on education field. Laura developed 20 technology skills that every educator should have to be good at with ICT literacy skills (Turner, 2005).

\section{Technology in Burkina Faso Teacher Education}

There is technology course in Burkina Faso teacher education curriculum. The technology course name Education Technology in curriculum has been taught as computer lecture. The content is based on basic computer course like hardware, software, operating system and MS office products and basic internet use knowledge. The course is seen to be so limited with 50 hours. The implementation of technology in education is facing some problems like the lack of infrastructure. Technology course has been given in computer lab with large number of student and few computers. To perform computer courses better and more efficiently students are divided into small groups to attend computer course. The minister of education with direction of teachers' education institutes has been working to improve the content of technology course in the pre-service teachers' education curriculum.

\section{STATEMENT OF THE PROBLEM}

Today, technology has been using in all sectors in our society. The field of education didn't stay away of this reality. The use of technology in developed countries is so advanced then the less developed countries like SubSaharan African countries. There, the use of technology is low. However, those countries try to use technology in education but the level is still limited, especially in teachers' training institutions. In Burkina Faso people are aware of the impact of technology all sectors of life and also the added value that technology can bring as opportunity be add value for the development of education. So what's about pre-teachers technology knowledge and skills?

\section{Research Questions}

What are the Secondary school pre-service teachers' technology skills levels of Burkina Faso?

$\checkmark$ Is there any difference between gender?

$\checkmark$ Is there any difference between education level?

$\checkmark$ Is there any difference according to field of study?

$\checkmark$ Is there any difference on the situation to have personal computer or not?

\section{Aim and Objectives of the Study}

The aim of this study is to determine Burkina Faso secondary school pre-service teachers' technology skills. The results of the study can be useful for policy to get real information that can help them to take beneficial decision to improve the content of ICT course on pre-service teachers' education curriculum.

\section{METHODOLOGY}

To achieve the objectives of this study survey method of quantitative research has been used. Survey research method are procedures in quantitative research in which investigators administer a survey to a sample in order to describe the attitudes, opinions, behaviors or characteristics of the population.

\section{Data Collection Method and Population}

The target population for the study was Burkina Faso Secondary School Pre-Service Teachers. The study was conducted in Burkina secondary teacher education public institute. A simple random sampling technique was used 
Pedagogical Research, 4(1), em0028

Table 1. Technology Skills Level

\begin{tabular}{cc}
\hline Interval & Level \\
\hline $3.00-4.00$ & High \\
\hline $2.00-2.99$ & Medium (moderate) \\
\hline $1.00-1.99$ & Low \\
\hline
\end{tabular}

Table 2. Demographic information

\begin{tabular}{|c|c|c|c|}
\hline Variable & Category & Frequency & Percent \\
\hline \multirow{3}{*}{ Gender } & Male & 429 & 80.3 \\
\hline & Female & 105 & 19.7 \\
\hline & Total & 534 & 100 \\
\hline \multirow{3}{*}{ Education level } & Associate degree & 263 & 49.3 \\
\hline & Bachelor degree & 271 & 50.7 \\
\hline & Total & 534 & 100 \\
\hline \multirow{5}{*}{ Field of Study } & Science & 280 & 52.4 \\
\hline & Literature & 127 & 23.8 \\
\hline & Technic & 67 & 12.5 \\
\hline & Sports & 60 & 11.2 \\
\hline & Total & 534 & 100 \\
\hline \multirow{3}{*}{ Computer possession } & Yes & 347 & 65.0 \\
\hline & $\mathrm{No}$ & 187 & 35.0 \\
\hline & Total & 534 & 100 \\
\hline
\end{tabular}

to administer the survey. Data was collected from 534 pre-service teachers of High School of Education (ENS; "Ecole Normale Supérierur") of Norbert Zongo University and Institute Of Sciences (IDS; "Institut Des Sciences") of Ouaga II University during 2 weeks on October 2017.

\section{Data Collection Tools}

According to the objective of the study, an appropriate data collection tool has been chosen after literature review. So pre-service teachers' technology skill, technology beliefs and technology barriers scales developed by Brush was chosen. This scale is usable as measuring instrument both for pre-service and in service teachers (Brush et al., 2008). Technology skill scale was divided on 6 sub-factors basic computer operation (create, save copy and delete files etc...); productivity software (MS word, Excel, Power Point); electronic communication (use of e-mail), electronic references (cd, usb), world wide web and multimedia with a total of 32 items on 4 type such as (1) $\mathrm{i}$ can't do this, (2) i can do this with some assistance, (3) i can do this independently and (4) i can teach others how to do this. In additional to the scale personal information was included as gender, education level, filed of study and computer possession.

\section{Data Analysis}

The analysis was done by using SPSS 22 after checking up the cronbach Alpha coefficient test validity and reliability for descriptive statistics. The cronbach alpha coefficient find as 0.95 were higher than 0.75 request for social sciences study validity and reliability. So t-test (Independant Sample test) and ANOVA one way analysis of variance ANOVA with post-hoc (Tukey HSD) test was applied according to research question with $\mathrm{p}<.05$ for significance sufficient in relationship difference analysis .

To determine the level of pre-services teachers technology skills, the range of evaluation on arithmetic average of the scores was determined as (4-1)/4=0.75 (Kan, 2009) and resume on Table 1.

According to Table 1 average lower than 2 are defined as low level, moderate level between 2 and 3 then averages more than 3 was determined as high level.

\section{RESULTS}

In this section, research questions and statistical description results were reported and been analyzed. Demographic information of the participant was made up with variable as gender, education level, field of study and personal computer possession case. Demographic information of the participants is given on Table 2.

As shown in the statistical information in Table 2, $429(80.3 \%)$ of the participants were male and $105(19.7 \%)$ were female. According to education level $263(49.30 \%)$ associate degree and $271(50.70 \%)$ were in bachelor degree. Field of study science department (mathematics, physics, chemistry, biology) 280 (52.4\%), literature (English, French, philosophy, history, geography) 127 (23.8\%), technical (Electricity), 67 (12.5\%) and sports (Sport and Physical Education) showed $60(11.2 \%)$. The status of those who have a computer were $347(65 \%)$ and $187(35 \%)$ do not own computers. 
Table 3. Descriptive Statistics of Pre-service Teachers' Technology Skills

\begin{tabular}{lcc}
\hline & \multicolumn{2}{c}{$\mathrm{n:534}$} \\
\cline { 2 - 3 } & $\mathrm{X}$ & $\mathrm{Ss}$ \\
\hline Basic Operation & 2.23 & .66 \\
\hline Productivity Software & 2.21 & .72 \\
\hline Electronic Communication & 2.08 & .86 \\
\hline Electronic References & 1.81 & .76 \\
\hline World Wide Web) & 2.19 & .58 \\
\hline Multimedia & 1.93 & .63 \\
\hline & $\mathbf{2 . 1 1}$ &. $\mathbf{5 5}$ \\
\hline
\end{tabular}

Table 4. Results of Techonology Skills According to Gender

\begin{tabular}{|c|c|c|c|c|c|c|c|}
\hline & Gender & $\mathrm{n}$ & $\mathrm{x}$ & Ss & Sd & $\mathrm{t}$ & $\mathbf{P}$ \\
\hline \multirow{2}{*}{ Basic Operation } & Male & 429 & 2.28 & .67079 & \multirow{2}{*}{532} & \multirow[b]{2}{*}{5.37} & \multirow{2}{*}{$.000^{*}$} \\
\hline & Female & 105 & 2.03 & .58734 & & & \\
\hline \multirow{2}{*}{ Productivity Software } & Male & 429 & 2.26 & .73280 & \multirow{2}{*}{532} & \multirow{2}{*}{5.65} & \multirow{2}{*}{$.000 *$} \\
\hline & Female & 105 & 2.00 & .65116 & & & \\
\hline \multirow{2}{*}{ Communication } & Male & 429 & 2.11 & .87788 & \multirow[b]{2}{*}{32} & \multirow{2}{*}{6.82} & \multirow{2}{*}{$.000^{*}$} \\
\hline & $\overline{\text { Female }}$ & 105 & 1.95 & .79806 & & & \\
\hline \multirow{2}{*}{ Electronic References } & Male & 429 & 1.83 & .78339 & \multirow{2}{*}{532} & \multirow{2}{*}{4.47} & \multirow{2}{*}{$.000 *$} \\
\hline & $\overline{\text { Female }}$ & 105 & 1.73 & .70743 & & & \\
\hline \multirow{2}{*}{ Worlde Wide Web } & Male & 429 & 2.23 & .57331 & \multirow{2}{*}{532} & \multirow{2}{*}{2.22} & \multirow{2}{*}{$.026^{*}$} \\
\hline & Female & 105 & 2.02 & .62148 & & & \\
\hline \multirow{2}{*}{ Multimedia } & Male & 429 & 1.96 & .62650 & \multirow{2}{*}{532} & \multirow{2}{*}{2.25} & \multirow{2}{*}{$.025^{*}$} \\
\hline & Female & 105 & 1.80 & .65619 & & & \\
\hline \multirow{2}{*}{ Technology Skills } & Male & 429 & 2.15 & .56685 & \multirow{2}{*}{532} & \multirow{2}{*}{2.25} & \multirow{2}{*}{$.000 *$} \\
\hline & Female & 105 & 1.94 & .54527 & & & \\
\hline
\end{tabular}

$\mathbf{P}<.05^{*}$

Table 5. Results of Techonology Skills According to Education Level

\begin{tabular}{|c|c|c|c|c|c|c|c|}
\hline & Education level & $\mathrm{n}$ & $\mathbf{x}$ & Ss & Sd & $t$ & $\mathbf{P}$ \\
\hline \multirow{2}{*}{ Basic Operation } & Associate degree & 263 & 2.05 & .56738 & 532 & 6.1 & $.000^{*}$ \\
\hline & Bachelor degree & 271 & 2.39 & .70480 & & & \\
\hline \multirow{2}{*}{ Productivity Software } & Associate degree & 263 & 2.06 & 61910 & 532 & 4.82 & $.000^{*}$ \\
\hline & Bachelor degree & 271 & 2.35 & .78717 & & & \\
\hline \multirow{2}{*}{ Communication } & Associate degree & 263 & 1.82 & .73202 & 532 & 7.16 & $000 *$ \\
\hline & Bachelor degree & 271 & 2.33 & .90880 & & & \\
\hline \multirow{2}{*}{ Electronic References } & Associate degree & 263 & 1.65 & .69769 & 532 & 9.12 & .297 \\
\hline & Bachelor degree & 271 & 1.97 & .80351 & & & \\
\hline \multirow{2}{*}{ Worlde Wide Web } & Associate degree & 263 & 2.10 & .54459 & 532 & 3.25 & $.020^{*}$ \\
\hline & Bachelor degree & 271 & 2.27 & .61821 & & & \\
\hline \multirow{2}{*}{ Multimedia } & Associate degree & 263 & 1.86 & .57503 & 532 & 2.51 & $.003^{*}$ \\
\hline & Bachelor degree & 271 & 2.00 & .68268 & & & \\
\hline \multirow{2}{*}{ Technology Skills } & Associate degree & 263 & 1.98 & .46977 & 532 & 5.47 & $.000 *$ \\
\hline & Bachelor degree & 271 & 2.24 & .62362 & & & \\
\hline
\end{tabular}

$\mathbf{P}<.05^{*}$

Following the research question the result of the main research question is given on Table 3 .

When statistical information on Table 3 are examined technology skill general average $(x=2.11)$ show that Burkina Faso secondary school pre-service teachers feel moderately competent. When we look on details it seems that on basic operation $(x=2.23)$, productivity software $(x=2.21)$ and World Wide Web $(x=2.19)$ and electronic communication $(x=2.08)$ sub-factors the pre-service teachers level were moderated but on multimedia $(x=1.93)$ and electronic references $(x=1.81)$ technology sub-factors indicated that pre-service teachers level were low. These results show that Burkina Faso secondary school pre-service teachers need to improve their skills in technology.

Regarding to reach question if there is a different on gender variable t-test was applied and the descriptive statistics results is given on Table 4.

As the t-test results in Table 4 are examined, the technology skills and details with sub-factors show a significant difference according to the gender variable $[\mathrm{t}(532)=2.25, \mathrm{p}<.05]$. The technological skills values of male $(\mathrm{x}=$ 2.15) were found to be statistically high than female $(x=1.94)$. Male pre-service teachers were more confident with technology than female. This situation can be explained by social and cultural reasons in Africa. In SubSaharan African countries men are so closer to technology than women.

Result related to education level is given on Table 5. 
Table 6. Results of Technology Skills According to Field of Education

\begin{tabular}{|c|c|c|c|c|c|c|}
\hline Field of Education & n & \multicolumn{2}{|r|}{$\mathbf{x}$} & \multicolumn{3}{|c|}{ Ss } \\
\hline A-Science & 280 & \multicolumn{2}{|r|}{2.05} & \multicolumn{3}{|c|}{.47792} \\
\hline B-Literature & 127 & \multicolumn{2}{|r|}{2.02} & \multicolumn{3}{|c|}{.56130} \\
\hline C-Technic & 67 & \multicolumn{2}{|r|}{2.74} & \multicolumn{3}{|c|}{.56805} \\
\hline D- Sports & 60 & \multicolumn{2}{|r|}{1.74} & \multicolumn{3}{|c|}{.52945} \\
\hline Total & 534 & \multicolumn{2}{|r|}{2.11} & \multicolumn{3}{|c|}{.56805} \\
\hline Variance source & Sum of squares & Sd & Means of squares & $\mathbf{F}$ & $\mathbf{P}$ & Means \\
\hline Inter group & 30.732 & 3 & 10.244 & 38.346 & $.000 *$ & $\mathrm{~A}-\mathrm{C}$ \\
\hline Within group & 141.257 & 530 & .267 & & & C-B \\
\hline Total & 171.990 & 533 & & & & C-D \\
\hline
\end{tabular}

Table 7. Results of Techonology Skills Regarding Computer Possession

\begin{tabular}{|c|c|c|c|c|c|c|c|}
\hline & Computer & $\mathrm{n}$ & $\mathbf{x}$ & Ss & Sd & $\mathbf{t}$ & $\mathbf{P}$ \\
\hline \multirow{2}{*}{ Basic Operation } & Yes & 347 & 2.46 & .62892 & 532 & 12.91 & $.000 *$ \\
\hline & No & 187 & 1.79 & .46945 & & & \\
\hline \multirow{2}{*}{ Productivity Software } & Yes & 347 & 2.43 & .70863 & 532 & 10.56 & $.000 *$ \\
\hline & No & 187 & 1.80 & .55490 & & & \\
\hline \multirow{2}{*}{ Communication } & Yes & 347 & 2.28 & .87770 & 532 & 7.64 & $.000 *$ \\
\hline & No & 187 & 1.71 & .70431 & & & \\
\hline \multirow{2}{*}{ Electronic References } & Yes & 347 & 1.94 & .79712 & 532 & 5.27 & $.021 *$ \\
\hline & No & 187 & 1.58 & .65568 & & & \\
\hline \multirow{2}{*}{ World Wide Web } & Yes & 347 & 2.33 & .57572 & 532 & 8.12 & .135 \\
\hline & No & 187 & 1.92 & .51557 & & & \\
\hline \multirow{2}{*}{ Multimedia } & Yes & 347 & 2.09 & .63753 & 532 & 8.43 & .005 \\
\hline & No & 187 & 1.63 & .51322 & & & \\
\hline \multirow{2}{*}{ Technology Skills } & Yes & 347 & 2.29 & .55303 & 532 & 11.49 & $.000 *$ \\
\hline & No & 187 & 1.76 & .41436 & & & \\
\hline
\end{tabular}

$\mathbf{P}<.05^{*}$

When results of the t-test on Table 5 are examined, it is seen that there is a significant difference technology skill in general between the pre-service teacher according to education level $\left[\mathrm{t}_{(532)}=5.47, \mathrm{p}<.05\right]$, expect on subfactor electronic references. The technological skills values of bachelor degree $(x=2.24)$ were found to be statistically higher than associate degree $(\mathrm{x}=1.98)$. So pre-service teachers with bachelor degree were more confident with technology than associate degree.

Results question related to field of education regarding technology skills ANOVA test is given on Table 6.

When Table 6 is examined, the distribution of pre-service teachers according to the technology skill was found as science $(x=2.05)$, literature $(x=202)$, technic $(x=2.74)$ and sports $(x=1.74)$. Significant differences $[F(5-.530)=$ $38.346, \mathrm{p}<.05$ ] was found between the pre-service teachers on technology skills regarding of the field of study. It is seen that technic department pre-service teachers were more competent than the sciences, literature and sports. This difference can be explained by the fact that in technic department teachers are not only very close to technology tools but also use them more than the other departments.

Result related to computer possession is given on Table 7.

When results of the t-test in Table 7 are examined, it is seen that there is a significant difference on technology skills in general between the pre-service teachers with computer and those without computer $[\mathrm{t}(532)=11.49, \mathrm{p}$ $<.05$ ], expect on World Wide Web and multimedia sub-factors. The technological skills values of pre-service teachers with computer $(x=2.29)$ were found to be statistically high than those without computer $(x=1.76)$. So preservice teachers with computer were more confident with technology than those without computer on their possession. This difference is due to the fact that pre-service teachers who have computers use them frequently and developed technology skills through their proximity with computer.

\section{CONCLUSION}

At the end of this study the results revealed that Burkina Faso secondary school pre-service teachers technology skills were so moderate in general and more particularly on basic computer operation (create, save copy and delete files...), in use of productivity software (MS Word, Excel, Power Point) and electronic communication (use of email). However, on World Wide Web and multimedia the result has indicated that the pre-service skills were low. Similarly study done on Sub-Saharan African countries share almost same result. A study made in Nigeria on teacher candidates skills on ICT literacy indicted that teachers ICT literacy were low (Garba, 2014). A study on 
ICT qualifications, perceptions and practices of secondary school social science teachers in Ghana, concluded that the teachers' ICT literacy skills and competences were low (Andoh, 2012). In another study, it was reported African francophone countries teachers had low ICT competencies (Tamboura, 2010). Comparative analyzes on gender education level, field of education, possession of computer showed differences. Male pre-service teachers were more competent than female. Bachelor degree pre-service teachers have advanced on associate degree. Technic department pre-service teachers had high level than other department science, literature and sports. Pre-service teachers with computer on their possession seem to be more confident with technology skills those who don't have personal computer.

\section{RECOMMENDATION}

As the results revealed that Burkina Faso secondary school pre-service teachers' technology skills were so moderate. An important recommendation is to ask minister in charge of education and the directorate of education institutes to work to improve the content of technology course in the pre-service teachers' education.

This study was limited to secondary school pre-service teachers; so research can be extended also in service teacher. Future research may include qualitative research method (e.g., interviews, case studies) to examine the teachers technology skills in depth. Similar study can be expanded other factors affecting teachers' use of technology in education like pre-service and in-service teachers' attitudes, belief and barriers regarding technology integration in education. Academicians on field of teacher education institute should develop a special technology skill standard evaluation instruments as UNSECO, ISTE and some country developed their own instrument.

\section{REFERENCES}

Andoh, B. C. (2012). An Exploration of Teachers' Skills, Perceptions and Practices of ICT in Teaching and Learning in the Ghanaian Second-Cycle Schools. Contemporary Educational Technology, 3(1), 36-49.

Becta. (2004). A review of the research literature on barriers to the uptake of ICT by teachers. Available at: http:// dera.ioe.ac.uk/1603/1/becta_2004_barrierstouptake_litrev.pdf (Accessed 25 July 2018)

Brush, T., Glazewski, K. D. and Hew, K. F. (2008). Development of an Instrument to Measure Preservice Teachers' Technology Skills, Technology Beliefs, and Technology Barriers. Computers in the Schools: Interdisciplinary Journal of Practice, Theory, and Applied Research, 112-125. https:// doi.org/10.1080/07380560802157972

Garba, A. S. (2014). Impact of ICT Course on Pre-Service Teachers Acquisition of ICT Literacy Skills and Competence in Nigeria. International Journal of Modern Education Research International Journal of Modern Education Research.

Herzig, R. (2004). Technology and its impact in the classroom. Computers and Education, 42(2), 111-131. https://doi.org/10.1016/S0360-1315(03)00067-8

Hew, K. F. and Brush, T. (2007). Integrating technology into K-12 teaching and learning: current knowledge gaps and recommendations for future research. Educational Technology Research and Development, 55, 223-253. https://doi.org/10.1007/s11423-006-9022-5

Jo, T., Johan, V. B., Guoyuan, S., Joke, V., Petra , F. and Anne, O.-L. (2012). Preparing pre-service teachers to integrate technology in education: A synthesis of qualitative evidence. Computers and Education, 59, 134-144. https://doi.org/10.1016/j.compedu.2011.10.009

Kan, A. (2009). Ölçme sonuçlar üzerinde istatistiksel işlemler [Statistical operations on measurement results]. Ankara: Ani.

Keengwe, J. and Onchwari, G. (2008). Computer technology integration and student learning: Barriers and promise. Journal of Science Education and Technology, 17, 560-565. https://doi.org/10.1007/s10956-008-9123-5

Livingstone, S. (2010). Critical reflections on the benefits of ICT in education. Oxford Review of Education, 38(1), 924. https://doi.org/10.1080/03054985.2011.577938

Tamboura, Y. (2010). Attitudes des enseignants du secondaire face à l'intégration des TIC dans les pratiques de classe: Etat des lieux des écoles concernées par l'Agenda Panafricain en Afrique francophone. Available at: http:/ / www.frantice.net/index.php?id=269

Tezci, E. (2010). Attitudes and knowledge level ofteachers in ICT use: The case of Turkish teachers. International Journal of Human Sciences.

Turner, L. (2005). 20 Technology Skills Every Educator Should Have. T.H.E. Available at: http://thejournal.com/articles/17325 
Usluel, K. Y., Mumcu, K. F. and Demiraslan, Y. (2007). Öğrenme-Öğretme Sürecinde Bilgi Ve İletişim Teknolojileri: Öğretmenlerin Entegrasyon Süreci Ve Engelleriyle İlgili Görüşleri Ict in The Learning-Teaching Process: Teachers'views on The Integration and Obstacles. Hacettepe Üniversitesi Eğitim Fakültesi Dergisi, 32, 164178.

Webb, M. and Cox, M. (2004). A Review of Pedagogy Related to Information and Communications Technology. Technology, Pedagogy and Education, 13(3). https:// doi.org/10.1080/14759390400200183 